Acta Botanica Brasilica - 35(4): 703-706. October-December 2021. doi: 10.1590/0102-33062020abb0536

\title{
A window of opportunity: a recent exotic palm invader can still be eradicated in an Atlantic Forest Protected Area
}

\author{
Suamyr Taconi** (D), Rodrigo Zucaratto ${ }^{1}$ (1) and Alexandra S. Pires ${ }^{1}$ (i)
}

Received: December 22, 2020

Accepted: May 2, 2021

\begin{abstract}
Exotic palms are introduced as ornamental all over the world, with some of them become invasive. Here, we characterize the population status and the stage of invasion of the exotic palm Caryota urens in an Atlantic Forest Protected Area, southeastern Brazil. Palms were sampled in 2019 and 2020, in fifteen 10 x $10 \mathrm{~m}$ plots, placed from an alley of planted reproductive palms. All individuals inside plots were marked and classified in ontogenetic stages. The number of sampled individuals was 110 in 2019 and 114 in 2020; palms were recorded in six plots in 2019 (the furthest 330 $\mathrm{m}$ from the alley) and in eight plots in 2020 (the furthest $420 \mathrm{~m}$ from the alley). In 2020, most palms were on the earlier ontogenetic stages (seedlings and infants, $86 \%$ ), but we also recorded juveniles (10.5 \%) and immatures (3.5\%), values similar to those found in 2019. The population structure observed and the natural expansion of the species inside the forest indicate that the palm has successfully established in the area and has become invasive. Management actions should be taken urgently in an attempt to contain the spreading to new locations or eradicate this palm from this protected area.
\end{abstract}

Keywords: Arecaceae, alien plants, biological invasion, Caryota urens, exotic species, toddy palm

Palms are among the main groups of ornamental plants that are introduced as exotic all over the world, and some of them have become invasive (Fehr et al. 2020; Zucaratto et al. 2020). Studies have shown that invasive palms can reduce seedling recruitment of other plant species (Zucaratto \& Pires 2014), cause the population decline of native palms (Mengardo \& Pivello 2014; Condé et al. 2016), and even generate cascade effects, causing, for example, an impoverishment of arthropod assemblage in invaded areas (Holmquist et al. 2011).

An exotic plant is categorized as invasive only when the species overcome the introduction-naturalization-

\footnotetext{
1 Departamento de Ciências Ambientais, Instituto de Florestas, Universidade Federal Rural do Rio de Janeiro, 23890-000, Seropédica, RJ, Brazil

* Corresponding author: suamyrtaconi.cj@gmail.com
} 
invasion continuum (Richardson et al. 2000; Blackburn et al. 2011). This characterization should be based according to three important criteria: the ability to sustain selfreplacing populations over several life cycles, the ability to produce reproductive offspring, and having the potential to spread over long distances (Richardson \& Pysek 2012). It is interesting to note that populations, and not species, are the invader unit. Therefore, the invasion status on the continuum should be assessed at a population level (Richardson \& Pysek 2012).

The fishtail palm Caryota urens L. is an exotic plant species native to South Asia and widely used as ornamental. This palm species has solitary stems that can reach 20 meters in height. A single adult tree can produce thousands of small fleshy fruits each year (c. 8,000 to 12,000 by infructescence; 1.5 to $2 \mathrm{~cm}$ in length; Henderson 2002). This high fruit production creates a massive propagule pressure and facilitates the integration of this palm in interaction networks (e.g. seed dispersal).

The introduction of $C$. urens in Brazil dates from the beginning of the 20th century, with the species being used as ornamental in São Paulo city (Romero \& Enokibara 2018). This palm is considered as a high risk of invasion in Brazil (Horus Institute 2020) and is present in almost all Brazilian states, including some protected areas (Moro \& Castro 2015;
Petri et al. 2018). One of these protected areas is the Park Lage (62.5 ha; Fig. 1), an Atlantic Forest fragment located in the Rio de Janeiro municipality, southeastern Brazil. Park Lage has a garden that was built between 1920 and 1930 as part of the ornamentation of an old residence, the Lage Mansion (currently the School of Visual Arts; Fig. 1) and was projected following the models of the European gardens (Memorialage 1975). Since this palm has a high risk of invasion and the population is used as criteria to categorize the invasion process, we aim (i) to identify the sites in the Park Lage with palm presence, (ii) to characterize palm population structure, (iii) to define the current stage of invasion of the palm in the Park.

In the Park's garden there is a group of 34 reproductive individuals of $C$. urens. Given the characteristics of these palms ( $\geq 15 \mathrm{~m}$ high) and the way some individuals were planted (forming alley), we considered the garden as the local of introduction of the $C$. urens in the area. We also defined this group of 34 reproductive palms as the population source of propagules. This information could be reinforced by a palm fruit collection realized in the Park Lage garden in 1982 (www.reflora.jbrj.gov.br/reflora). As the average lifespan of the palm is 25 years and the age of first reproduction about 15 years (Henderson 2002; Rajyalakshmi 2004), we
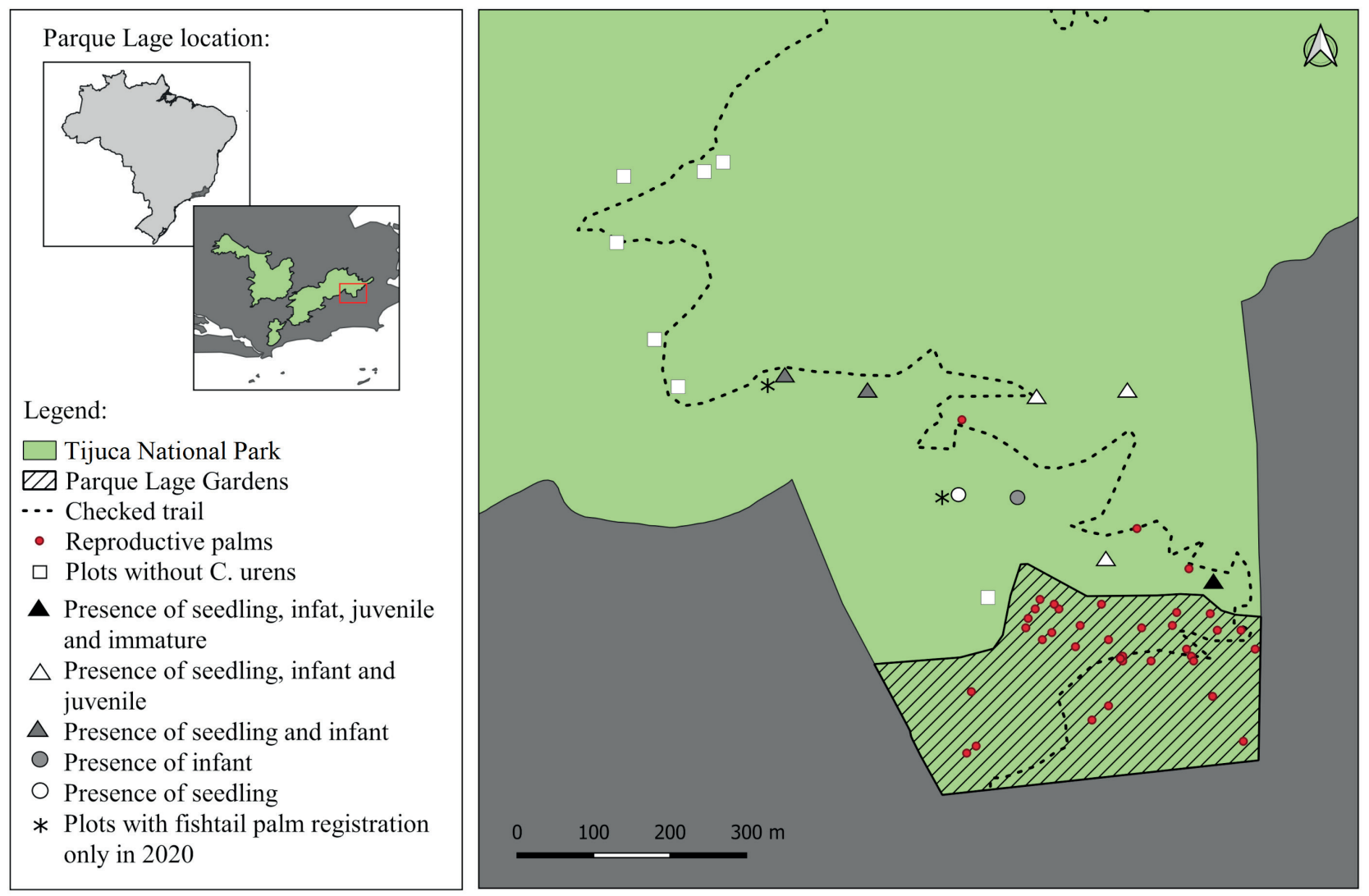

Figure 1. Location of the study area, Park Lage, which is part of the Tijuca National Park, Rio de Janeiro city, Brazil. The dashed line represents the existing trail in Park Lage that was checked for the occurrence of the exotic palm Caryota urens. The symbols represent the delimited plots. 
estimate that the species has been present in the garden for at least 53 years.

We collected the data during the years 2019 and 2020, in fifteen $10 \times 10 \mathrm{~m}$ plots at different distances from the source population. To demarcate plots, we traveled the trail connecting Park Lage gardens to Corcovado Mountain (Fig. 1). The plots were demarcated at a minimum distance of $10 \mathrm{~m}$ of the trail and with a mean distance of $100 \mathrm{~m}$ apart from each other. All individual palms inside the plots were marked (with numbered aluminum plates) and grouped in five ontogenetic stages (seedling, infant, juvenile, immature and reproductive), characterized according to the emergence of vegetative and reproductive structures (e. g., Portela \& Santos 2011). 'Seedlings' were those presenting only bifid leaves, 'infants' show at least one transitional leaf, 'juveniles' show at least one bipinate leaf, 'immatures' have apparent stems and 'reproductive individuals' have signals of present or past reproduction (spathes, inflorescences or infructescences). We used such information to determine areas with palm presence, to characterize the palm population structure, and to determine the current stage of invasion.

To define the stage of invasion of the palm we followed the model proposed by Blackburn et al. (2011). Such model considers as invader a species with a self-sustaining population in the wild, with individuals surviving and reproducing at a significant distance from the original point of introduction.

We counted 110 palm individuals in six plots in 2019, 76 were seedlings, 17 infants, 12 juveniles and 5 immatures. The farthest plot we registered palm presence in 2019 was at a distance of $330 \mathrm{~m}$ from the point of introduction (Fig. 1). In 2020 we counted 114 individual palms in eight plots, being 80 seedlings, 18 infants, 12 juveniles and 4 immatures. The farthest plot in which we registered palm presence in 2020 was at a distance of $420 \mathrm{~m}$ from the point of introduction (Fig. 1). We did not record reproductive individuals in the plots. However, we recorded three reproductive individuals in the trail, respectively at 50, 100 and $250 \mathrm{~m}$ away from the point of introduction, inside the forest area (Fig. 1). The population structure of the palm presented a J-reverse pattern, both in 2019 and 2020 (Fig. 2). Since the palm has a self-sustaining population, produces reproductive offspring, and is over long distances from the local of introduction, we considered that the species is in the spread stage of the invasion process.

The presence of the palm inside the forest showed a trend towards population expansion, indicating that the species has successfully established in the area. This could be reinforced by the population structure we observed. In the gardens of the Park Lage, where a reproductive population is found, is the lowest part of the study area, we observed most of the individuals in this area. As this main population grows, we observe a reduction of ontogenetic stages observed (Fig. 1), in the higher areas of the Park. How can we see that the invasion process is bottom-up?
Such observations have been also reported for other exotic palm spreading in a protected area in the Atlantic Forest (Nascimento et al. 2013). Also, seedlings inside the forest could indicate interaction between palm fruits and local fauna that are contributing to the expansion of the palm to new sites. In fact, studies have reported that resource rich exotic plants, like palms, can integrate interaction networks (e.g., seed dispersal) and attract frugivores that can spread their propagules to new locations (Heleno et al. 2013; Elsamol et al. 2019). Studies evaluating the interaction between local fauna and fruits of $C$. urens and how these interactions affect native plants would provide relevant information about the role of local fauna in the spread of this invasive palm.

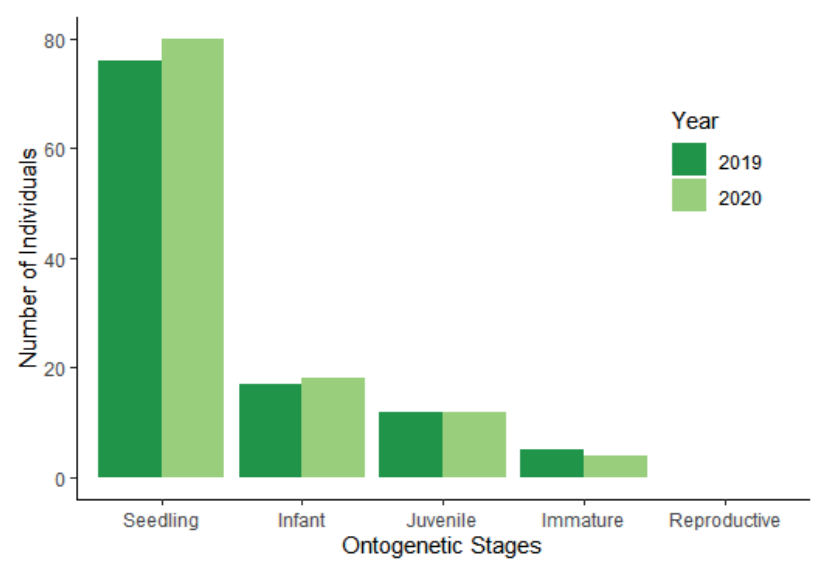

Figure 2. Population structure of the invasive palm Caryota urens during two consecutive years in Park Lage, Tijuca National Park, Rio de Janeiro city, Brazil.

Since the palm has a self-sustaining population and is spreading in natural areas of the Park Lage, management actions to contain the spread must be taken urgently. Such management actions would avoid the emergence of new foci of invasion and the negative impacts of this palm on the native species, as reported for other invasive palms (Zucaratto \& Pires 2014; Holmquist et al. 2011; Condé et al. 2016). Because the species present a small population and is restricted to a small area, such management actions could be efficient in eradicating the species from the area. The efficiency in eradicating invasive plants with small populations was demonstrated by Simberloff (2013). The author reported several examples of invasive plants with small populations that have been eradicated from protected areas, including a palm species also from Asia (Livistona chinensis (Jacq.) R.Br. ex Mart) and with similar characteristics to $C$. urens (size, fruit production).

To manage $C$. urens we recommend a modification of the two-step strategy (Moody \& Mack 1988), with both steps being applied simultaneously. This management technique states that management should start in an isolated or a small group of individuals and then methodically reduce the area of the main infestations. Thus, we recommend 
the removal of the adult palm individuals inside the plots and the other three observed out of the plots but inside the forest. Since these individuals are in a reduced number, removing them would be cheaper and easier (low cost, low human resources). To remove these reproductive palms we suggest cutting the apical meristems, a more viable alternative then cutting the entire palm. Such alternative also reduces the risks to other species that could be caused by felling large individuals ( $\geq 10 \mathrm{~m}$ ). Simultaneously, we recommend the removal of reproductive structures of the reproductive individuals in the garden of Park Lage. Removing such structures could prevent the development of new propagules, until the complete removal of these reproductive individuals is done

A post-palm removal monitoring is also highly recommended. This monitoring is important to avoid reinvasion by $C$. urens or an invasion by other exotic plants that are present in the area (Simberloff 2013). In parallel with palm removal, we also indicate the restoration of managed areas, with the planting of native plant species, as the palm Euterpe edulis Mart. (juçara palm). This native palm has a low population density in the Park Lage and is considered as vulnerable according to the red list of Brazilian Flora (CNCFlora 2012). So, planting E. edulis in the managed areas can provide similar food resources for the fauna, besides increase the population density of this species, helping in its preservation.

\section{Acknowledgements}

We thank Tijuca National Park staff, particularly Plinio Barboza, Katyucha Von Kossel, and the Park monitors for all the support to the study. We are also grateful to all colleagues that provided valuable help during fieldwork and the two anonymous reviewers who improve considerably the manuscript. ST received a scholarship from PIBIC/CNPq and ASP from CNPq (PQ 311158/2019-6).

\section{References}

Blackburn TM, Pysek P, Bacher S, et al. 2011. A proposed unified framework for biological invasions. Trends in Ecology and Evolution 26: 333-339.

CNCFlora - Centro Nacional de Conservação da Flora. 2012. Livro Vermelho da Flora do Brasil. Rio de Janeiro, Instituto de Pesquisas Jardim Botânico do Rio de Janeiro.

Condé TM, Silva F, Souza AL, et al. 2016. Exotic palms threatens native palms: a risk to plant biodiversity of Atlantic Forest. Revista Árvore 42: e4202016. doi: 10.1590/1806-90882018000200016
Elsamol KB, Sreekumar VB, Thasini VM, Nimisah ES. 2019. Avian frugivory and seed dispersal of an exotic palm Ptychosperma macarthurii (H. Wendl. ex H. J. Veitch) H. Wendl. ex Hook. f. Tropical Ecology 60: 159-162.

Fehr V, Buitenwerf R, Svenning JC. 2020. Non-native palms (Arecaceae) as generators of novel ecosystems: A global assessment. Diversity and Distributions 26: 1523-1538.

Heleno RH, Ramos JA, Memmott J. 2013. Integration of exotic seeds into an Azorean seed dispersal network. Biological Invasions 15:1143-54.

Henderson A. 2002. Evolution and ecology of palms. New York, The New York Botanical Garden Press.

Holmquist JG, Schmidt-Gengenbach J, Slaton MR. 2011. Influence of invasive palms on terrestrial arthropod assemblages in desert spring habitat. Biological Conservation 144: 518-525.

Hórus Institute. Análise de Risco para Plantas Invasoras: Caryota urens. http://www.institutohorus.org.br/download/AR\%20Plantas\%20 Horus/AR\%20Plantas\%20Caryota\%20urens.pdf. 15 May 2020.

Memorialage. 1975. História do Parque Lage / Escola de Artes Visuais. http:// acervo.memorialage.com.br/xmlui/handle/123456789/1950\#page/1/ mode/1up. 27 Aug. 2020.

Mengardo ALT, Pivello VR. 2014. The effects of an exotic palm on a native palm during the first demographic stages: contributions to ecological management. Acta Botanica Brasilica 28: 552-558.

Moody ME, Mack R. 1988. Controlling the spread of plant invasions - the importance of nascent foci. Journal of Applied Ecology 25: 1009-1021.

Moro MF, Castro ASF. 2015. A check list of plant species in the urban forestry of Fortaleza, Brazil: where are the native species in the country of megadiversity? Urban Ecosystems 18: 47-71.

Nascimento MT, Araujo RM, Dan ML, Netto EBF, Braga JMA. 2013. The Imperial Palm (Roystonea oleracea (Jacq.) O.F. Cook) as an invasive species of a wetland in Brazilian Atlantic forest. Wetlands Ecology and Management 21: 367-371.

Petri L, Aragaki S, Gomes EPC. 2018. Management priorities for exotic plants in an urban Atlantic Forest reserve. Acta Botanica Brasilica 32: 631-641.

Portela RC, Santos FAM. 2011. Ontogenetic stages characterization for three palm species: a proposal of standardization for population dynamics studies. Brazilian Journal of Botany 34: 523-535.

Rajyalakshmi P. 2004. Caryota Palm Sago - A potential yet underutilized natural resource for modern starch industry. Indian Journal of Natural Products and Resources 3: 144-149.

Richardson DM, Pysek P, Rejmánek M, Barbour MG, Panetta FD, West CJ. 2000. Naturalization and invasion of alien plants: concepts and definitions. Diversity and Distributions 6: 93-107.

Richardson DM, Pysek P. 2012. Naturalization of introduced plants: ecological drivers of biogeographical patterns. New Phytologist 196: 383-396.

Romero LB, Enokibara M. 2018. Repertório vegetal da arborização urbana do Estado de São Paulo no início do Século XX. Revista Nacional de Gerenciamento de Cidades 39: 76-94.

Simberloff D. 2013. Eradication - pipe dream or real option? In: Foxcroft LC, Pysek P, Richardson DM, Genovesi P. (eds.) Plant invasions in protected areas: patterns, problems and challenges. Dordrecht, Springer. p. 549-559.

Zucaratto R, Pires AS. 2014. The exotic palm Roystonea oleracea (Jacq.) O. F. Cook (Arecaceae) on an island within the Atlantic Forest Biome: naturalization and influence on seedling recruitment. Acta Botanica Brasilica 28: 417-420.

Zucaratto R, Santos GS, dos Santos Pires A, Bergallo HG. 2020. Coalescing past and present to predict the future: historical attributes and current situation of a non-native palm on an island in the Atlantic Forest. Journal of Coastal Conservation 24: 1-7. 